\title{
Detection of hemoglobinopathies in patients of anaemia using high performance liquid chromatography (HPLC) - a hospital based prospective study
}

\author{
Mahesh Kumar $\mathbf{U}^{1}$, Devisri Y. ${ }^{2}$ \\ ${ }^{1}$ Dr. Mahesh Kumar U, Professor \& HOD, Department of Pathology, Mahavir Institute of Medical Sciences, Vikarabad, \\ ${ }^{2}$ Miss. Devisri Y, Undergraduate Medical Student, Prathima Institute of Medical Sciences, Karimnagar.
}

Corresponding Author: Dr. Mahesh Kumar U, Prof \& HOD, Department of Pathology, Mahavir Institute of Medical Sciences, Vikarabad, Telangana, India. E-mail id: maheshdearmedico@yahoo.co.in

\begin{abstract}
Introduction: In India, the gene frequency of hemoglobinopathies is $4.2 \%$, with a population over 1 billion and over 12000 infants born each year have a clinically significant hemoglobinopathies. In various parts of India, the prevalence of $\beta$-Thalassemia is different. $\beta$ - Thalassemia has a high prevalence in some communities, such as Sindhi, Luvana, Tribes, and Rajputs. There is no such study done in and around Karimnagar district of Telangana state, therefore a preliminary hospital-based study was carried out. Materials \& Methods: In this cross-sectional hospital-based study, target group adopted was anaemic patients $(<11 \mathrm{gm} / \mathrm{dl})$. Haemoglobin and Red Blood Cell indices were measured on automated- three part differential cell counter. All these samples were analysed for haemoglobin disorders by BIORAD 'VARIANT' HPLC machine. Results: Among the cases, Karimnagar (62), Adilabad (143) and Medak (15) districts amounting for 220 cases in which $36(16.36 \%)$ were having Hemoglobinopathies of which Karimnagar had 12 cases, Adilabad 23 cases and Medak had one case. The present study also revealed the prevalence of hemoglobinopathies according to caste. Mala caste had a higher frequency 12/36 (33.3\%) followed by Munnur Kapu 6/36 (16.6\%) and Christians 5/36(13.8\%). This might be due to higher population of mala community as compared to others reported to the hospital. Conclusion: The data regarding prevalence and distribution can be useful in prevention and management of various hemoglobinopathies which may play a vital role in the hospital blood bank as well as in the formulation of transfusion policies.
\end{abstract}

Keywords: Hemoglobinopathies, HPLC, Thalassemia

\section{Introduction}

India has multiple geographical, ethnic, religious and language divisions [1]. Traditionally, marriages are within these subdivisions only resulting in difficulties in estimating the burden of genetic diseases at local and national level. In India, the gene frequency of hemoglobinopathies is $4.2 \%$, with a population over 1 billion and over 12000 infants born each year have a clinically significant hemoglobinopathies. According to world health organization (WHO), 5\% of the world population is a carrier for Hemoglobin disorders [3].

In various parts of India, the prevalence of $\beta$ Thalasemia is different: $6.5 \%$ in Punjab, $8.4 \%$ in Tamilnadu, $4.3 \%$ in south India, and $3.5 \%$ in Bengal. $\beta$ Thalasemia has a high prevalence in some communities, such as Sindhi, Luvana, Tribes, and Rajputs [4]. Approximately 30 million Indians are carriers of $\beta$ -

Manuscript received: $14^{\text {th }}$ January 2019

Reviewed: $24^{\text {th }}$ January 2019

Author Corrected: $30^{\text {th }}$ January 2019

Accepted for Publication: $5^{\text {th }}$ February 2019
Thalasemia and 7000 babies with $\beta$-Thalasemia are born every year. In different ethnic groups, the variation in carrier rate is between $0 \%-17 \%$ [5] So, early diagnosis of these carriers is essential to prevent and reduce the incidence of thalassemia major. Diagnosis of hemoglobinopathies in most centres in India relies upon conventional methods like, clinical and family history, complete blood counts (CBC), red cell indices, $\mathrm{HbA} 2$, $\mathrm{HbF}$ estimation, sickling test, and $\mathrm{Hb}$ electrophoresis.

Various limitations of these methods have been felt in recent years. One of the most important is the difficulty in the identification of $\mathrm{Hb}$ variants with same electrophoretic mobility, such as in $\mathrm{A} 2 / \mathrm{E} / \mathrm{C} / \mathrm{O}-\mathrm{Arab}$ and $\mathrm{S} / \mathrm{D} / \mathrm{G} / \mathrm{Q} /$ Lepore. Another issue comes up while diagnosing certain compound heterozygous states such as, $\mathrm{HbD}+\mathrm{HbE}, \mathrm{HbS}+\beta$ thalassemia, $\mathrm{HbS}+\mathrm{HbD}, \mathrm{HbE}$ $+\beta$ thalassemia, $\mathrm{HbD}+\beta$ thalassemia [6]. Therefore, an early and accurate diagnosis of hemoglobinopathies is required. One such reliable tool for diagnosis and early 
detection is cation exchange high performance liquid chromatography (CE-HPLC). With the incorporation of CE-HPLC in the diagnosis of various types of abnormal hemoglobins, the prevalence in various parts of the world along with the changing trends, can be accurately determined [7].

Cat ion exchange HPLC is emerging as one of the best methods for screening and detection of various hemoglobinopathies with rapid, reproducible and precise results [8].

It has the advantage of quantifying $\mathrm{Hb} \mathrm{F}$ and $\mathrm{Hb} \mathrm{A} 2$ along with haemoglobin variant screening in single and highly reproducible system. The simplicity of the automated system with internal sample preparation, rapid assay time, and accurate quantification of haemoglobin fractions makes this an ideal for routine clinical laboratory [9].

\section{Materials and Methods}

Place of Study: Prathima Institute of Medical Sciences and Hospital, Karimnagar, Telangana State.

Type of study: Cross sectional Hospital based study.

Duration of study: From $25^{\text {th }}$ June to $25^{\text {th }}$ Aug 2016 (two months duration).

Sampling Method: Convenience sampling method was used (since this was an ICMR STS project which was done only for two months).

Sample Size: Sample size was calculated by using Open Epi software for this cross sectional study. As the prevalence of Hemoglobinopathies in south India is $4.3 \%$, with $95 \%$ confidence interval and $5 \%$ precision, the sample size calculated was 62 cases [4]. Since our study is of 2 months duration, we could collect only 36 cases.

Sample collection: In this cross-sectional hospital-based study, target group adopted was anaemic patients $(<11 \mathrm{gm} / \mathrm{dl})$ attending Hospital. $2 \mathrm{ml}$ EDTA Blood samples were collected in clinical haematology lab. Details of clinical examination, history of blood transfusion, family history and consent were taken in all cases. Prior to the study institutional ethical committee clearance and informed consent was taken.

Haemoglobin and Red Blood Cell indices were measured on automated three-part differential cell counter using well mixed anticoagulated blood. Peripheral blood smears examination and Reticulocyte count study was also done in all the patients. The results of haemoglobin $(\mathrm{Hb})$, mean corpuscular volume (MCV), mean corpuscular haemoglobin $(\mathrm{MCH})$, mean corpuscular haemoglobin concentration (MCHC), red blood cell (RBC) count and red cell distribution width (RDW) was correlated with peripheral smear examination. All these samples were analysed for haemoglobin disorders by BIORAD 'VARIANT' HPLC machine. It utilizes the principle of high performance liquid chromatography (HPLC). An $\mathrm{HbA} 2 / \mathrm{F}$ calibrator and two level controls were analysed at the beginning of each run. The total area acceptable was between- one million to three million.

The software delivers a printed report showing the chromatogram, with all the haemoglobin fractions eluted. The integrated peaks are assigned to manufacturer - defined "windows" derived from specific retention time (RT). This retention time is the time that elapses from the sample injection to the apex of the elution peak, of normal haemoglobin fraction and common variants. Table 1 show "windows" of established ranges in which common variants have been observed to elute using the Variant beta- thalassemia short program. The printed chromatogram shows all the haemoglobin fractions eluted, the retention times, the areas of the peaks and the values of different haemoglobin components. If a peak elutes at a retention time that is not pre-defined, it is labelled as an unknown. Each analytical cycle, from sampling to printing of results takes about 6.5 minutes. 
Original Research Article

Table-1: Manufacturer- assigned windows for Bio-Rad Variant II HPLC system [9]

Printed chromatogram shows all the haemoglobin fractions eluted, the retention times, the areas of the peaks and the values of different haemoglobin components.

\begin{tabular}{|c|c|}
\hline Peak name & Retention Time, min \\
\hline P1 window & $0.63-0.85$ \\
\hline F window & $0.98-1.2$ \\
\hline P2 window & $1.24-1.40$ \\
\hline P3 window & $1.40-1.90$ \\
\hline A0 window & $1.90-3.10$ \\
\hline A2 window & $3.30-3.90$ \\
\hline D window & $3.90-4.30$ \\
\hline S window & $4.30-4.70$ \\
\hline C window & $4.90-5.30$ \\
\hline
\end{tabular}

\section{Inclusion criteria}

1. Only Anaemic patients (i.e $<11 \mathrm{gm} / \mathrm{dl})$ attending Hospital were included

2. All cases where HPLC was performed were included

\section{Exclusion criteria}

1. Patients (i.e $>11 \mathrm{gm} / \mathrm{dl}$ ) attending Hospital were excluded

2. All cases where HPLC was not performed were excluded

\section{Results}

Total 220 subjects who presented with $\mathrm{Hb}<11 \mathrm{gm} / \mathrm{dl}$ were screened with HPLC for assessing hemoglobinopathies and among them, 36 subjects were diagnosed as having hemoglobinopathies by High performance liquid chromatography (HPLC) with its prevalence being 16.36\%. The subjects belonged to districts of Karimnagar, Adilabad and Medak districts of Telangana State. Prevalence was analysed on the basis of presence or absence of hemoglobinopathy in the screened anemic $(\mathrm{Hb}<11 \mathrm{gm} \%)$ cases.

Out of 36 cases, 20 were male and 16 were females. In females, the most common age group affected was 15-23 years, whereas in males, the most common age group affected was below 10 years [Table 2].

Table-2: Incidence and gender distribution of various Hemoglobinopathies $(\mathrm{n}=36)$

\begin{tabular}{|c|c|c|c|}
\hline Haemoglobin Pattern & Male & Female & Cases \\
\hline Beta thalassemia Trait & 01 & 00 & 01 \\
\hline Beta thalassemia Intermedia & 01 & 00 & $\mathbf{1 1}$ \\
\hline Beta thalassemia Major & 05 & 06 & 09 \\
\hline Hb S Homozygous & 04 & 00 & 02 \\
\hline Hb S Heterozygous & 02 & 05 & $\mathbf{1 2}$ \\
\hline Sickle - thalassemia & 07 & 16 & 36 \\
\hline
\end{tabular}

The major abnormality observed on HPLC was double heterozygous state (sickle-Beta thalassemia) accounting for 12 cases $(33 \%)$ then followed by beta thalassemia major 11 cases $(30.5 \%)$ and 9 cases $(25 \%)$ of Hb S homozygous. Beta thalassemia cases showed microcytosis, hypochromia and target cells on peripheral smear and sickle cells in sickle cell anaemia.

In Beta thalassemia major, mean $\mathrm{MCH}$ was $22.82 \mathrm{pg} / \mathrm{cell}$ and $21.15 \mathrm{pg} / \mathrm{cell}$ in the male and female, respectively. In Sickle - thalassemia trait, mean $\mathrm{MCH}$ was $21.61 \mathrm{pg} / \mathrm{cell}$ and $22.15 \mathrm{pg} / \mathrm{cell}$ in the male and female, respectively and in $\mathrm{Hb}$ $\mathrm{S}$ homozygous, mean was $24.27 \mathrm{pg} / \mathrm{cell}$ and $24.75 \mathrm{pg} / \mathrm{cell}$ in the male and female, respectively [Table 3 ]. 
Original Research Article

Table-3: Haematological parameters in different group of Hemoglobinopathies

\begin{tabular}{|c|c|c|c|c|c|}
\hline Haemoglobinopathies & $\begin{array}{c}\text { Hb (g/dl) } \\
\text { mean } \pm \text { S D }\end{array}$ & $\begin{array}{c}\text { RBC count } \pm \text { SD } \\
(\mathbf{m i l l i o n} / \mathbf{c m m})\end{array}$ & $\begin{array}{c}\text { MCV(fl) } \\
\text { mean } \pm \text { S D }\end{array}$ & $\begin{array}{c}\text { MCH (pg) } \\
\text { mean } \pm \text { SD }\end{array}$ & $\begin{array}{c}\text { MCHC (g/dl) } \\
\text { Mean } \pm \text { S D }\end{array}$ \\
\hline Beta thalassemia trait (01) & 8.9 & 4.7 & 62.5 & 23.1 & 30.56 \\
\hline Beta thalassemia major (11) & $2.1 \pm 1.4$ & $0.85 \pm 0.43$ & $58.73 \pm 5.2$ & $22.82 \pm 2.0$ & $39.56 \pm 2.3$ \\
\hline Beta thalassemia intermedia(01) & 8.9 & 4.7 & 62.5 & 23.1 & 30.56 \\
\hline Hb S Homozygous (09) & $4.1 \pm 1.7$ & $1.98 \pm 0.95$ & $61.33 \pm 2.2$ & $24.27 \pm 1.5$ & $30.16 \pm 1.3$ \\
\hline Hb S Heterozygous (02) & $8.7 \& 7.2$ & 4.9 and 4.1 & 58.01 and60.44 & 21.29 and 20.12 & 30.93 and 29.8 \\
\hline Sickle - thalassemia trait (12) & $3.9 \pm 1.1$ & $1.05 \pm 0.85$ & $59.36 \pm 3.3$ & $21.61 \pm 1.6$ & $30.61 \pm 1.4$ \\
\hline
\end{tabular}

Most of the cases were belonging to Adilabad (23) district followed by Karimnagar (12) and then Medak (01). Of which most cases were from mala caste/community (12) followed by munnur kappu (06) caste [Table $4 \& 5$ ].

Table-4: Area wise prevalence of Hemoglobinopathies

\begin{tabular}{|c|c|c|c|}
\hline S. $\mathbf{N}$ & $\begin{array}{c}\text { District } \\
(\mathbf{n = N o . ~ o f ~ s u b j e c t s ~} \mathbf{2 2 0})\end{array}$ & $\begin{array}{c}\text { No. of subjects with } \\
\text { Hemoglobinopathies (n=036) }\end{array}$ & Prevalence \% \\
\hline 01 & Adilabad district (143) & 23 & $63.88 \%$ \\
\hline 02 & Karimnagar district (62) & 12 & $33.33 \%$ \\
\hline 03 & Medak district (15) & 01 & $02.77 \%$ \\
\hline & & 36 & $100 \%$ \\
\hline
\end{tabular}

Table-5: Religion / Caste wise prevalence of Hemoglobinopathies.

\begin{tabular}{|c|c|c|c|}
\hline S. $\mathbf{~}$ & $\begin{array}{c}\text { Religion/Caste } \\
(\mathbf{n}=\mathbf{N o} \text { of subject }=\mathbf{2 2 0})\end{array}$ & $\begin{array}{c}\text { No. of subjects with } \\
\text { Hemoglobinopathies (n=036) }\end{array}$ & Prevalence \% \\
\hline 01 & Hindus (187) & 03 & $08.3 \%$ \\
\hline & Lambadi's (20) & 12 & $\mathbf{3 3 . 3 \%}$ \\
\hline & Mala (69) & 04 & $11.1 \%$ \\
\hline & Madiga (30) & 06 & $02.7 \%$ \\
\hline & Munnur Kapu (36) & 01 & $02.7 \%$ \\
\hline & Goud's (11) & 01 & $02.7 \%$ \\
\hline & Baare (03) & 01 & $02.7 \%$ \\
\hline 02 & Tenugu (10) & 01 & $02.7 \%$ \\
\hline & Bestha (04) & 01 & $02.7 \%$ \\
\hline
\end{tabular}

\section{Discussion}

The Indian population comprises numerous castes and communities, each revealing different genetic traits. The distribution of beta-thalasemia is not uniform in Indian subcontinent. The highest frequency of beta thalasemia trait is reported in Gujarat (10-15\%), followed by Sindh (10\%), Punjab (6.5\%), Tamil Nadu (8.4\%) and Maharashtra [15]. In our study, total screened subjects at Prathima institute of medical sciences were belonging to Karimnagar (62), Adilabad (143) and Medak (15) districts amounting for 220 cases in which 36 (16.36\%) were having Hemoglobinopathies of 
Original Research Article

which Karimnagar had 12 cases, Adilabad 23 cases and Medak had one case. Verma, et al screened 1180 subjects belonging from Uttar Pradesh in which 143 (12.1\%) were having Hemoglobinopathies [4]. Ambekar et al. reported the frequency of hemoglobinopathies in Western Maharashtra stating 106 (26.5\%) out of 400 subjects showing the presence of hemoglobinopathies [16]. Chopra et al. revealed that out of 1032 participant, $258(25 \%)$ cases had abnormal haemoglobin [17]. The issue of hemoglobinopathies in India is aggravated by the diversity of population. The gene frequency for various hemoglobinopathies varies across different regions of India. The rates of fertility, literacy and consanguinity in marriages are also diversified [4].

However, Patel J et al. reported the prevalence of hemoglobinopathies in Gujarat, mentioning that out of 428 subjects, 153(35.7\%) had Hemoglobinopathies [15] while their another study in year 2011 found higher prevalence up to 38.97\%. [18] Another study by Panda A et al. based on West Bengal population illustrated to prevalence of hemoglobinopathies was $20.47 \%$ [19]. Sachdev et al. reported 327 (12.6\%) hemoglobinopathies out of 2600 subjects [20]. This finding is correlating with our study result.

Comparing the haematological parameters of beta thalassemia major, it was correlating with Baruah et al [11] and Bhalodia JN et al [10] (Table 6). Uddin et al., observed that majority of hemoglobinopathy cases belong to neonatal to childhood period (0-15 years) followed by reproductive age group (16-45 years) and only a few cases of old age ( $\geq 46$ years) were detected in Bangladesh [21] This finding is correlating with our study result.

The present study (Table 2) revealed higher prevalence of hemoglobinopathies in males 20/36 (55\%) as compared to females 16/36 (44.44\%). A study by Chopra and co-workers reported that out of 258 abnormal cases, 136 (53\%) were males and 122 (47\%) were females [17] and Patel et al. found 62\% male 37.9\% female having hemoglobinopathies [15] while Uddin et al., reported an equal incidence of hemoglobinopathies in both males and females [21].

Table-6: Haematological parameters in different studies for beta thalassemia major

\begin{tabular}{|c|c|c|c|c|c|}
\hline Different studies & $\begin{array}{c}\text { Hb (g/dl) } \\
\text { mean } \pm \text { SD }\end{array}$ & $\begin{array}{c}\text { RBC count } \\
\pm \text { SD } \\
\text { million/cmm) }\end{array}$ & $\begin{array}{c}\text { MCV(fl) } \\
\text { mean } \pm \text { SD }\end{array}$ & $\begin{array}{c}\text { MCH } \\
\text { (p g) } \\
\text { mean } \pm \text { SD }\end{array}$ & $\begin{array}{c}\text { MCHC } \\
\text { (g/dl) } \\
\text { mean } \pm \text { SD }\end{array}$ \\
\hline Baruah et al (27) [11] & $3.8 \pm 2.1$ & $1.9 \pm 1.1$ & $66.3 \pm 8.5$ & $20.3 \pm 3.4$ & $30.7 \pm 3.8$ \\
\hline Bhalodia JN et al (01) [10] & 2.1 & 0.85 & 62.73 & 24.82 & 39.56 \\
\hline Present study (11) & $2.1 \pm 1.4$ & $0.85 \pm 0.43$ & $58.73 \pm 5.2$ & $22.82 \pm 2.0$ & $39.56 \pm 2.3$ \\
\hline
\end{tabular}

The present study also revealed the prevalence of hemoglobinopathies according to caste (Table 5). Mala caste had higher frequency 12/36 (33.3\%) followed by Munnur Kapu 6/36 (16.6\%) and Christians 5/36 (13.8\%). This might be due to higher population of mala community as compared to others reported to the hospital.

A study of Odisha (Orissa) state by Bhasin MK et al., reported that hemoglobinopathy is confined mostly to scheduled tribes (ST) or scheduled castes (SC) as compared to general caste [22] This finding is correlating with our study result.

Another study of Orissa by RS Balgir observed that majority of hemoglobinopathic patients belong to general castes for sickle cell disorders (64.6\%), $\beta$-thalasemia (79.6\%) and other hemoglobinopathies (91.3\%) [23]. This may be due to breeding isolation of the people from the general stream and strictly following the tribal endogamy.

\section{Conclusion}

In our country major cause of anaemia is nutritional deficiencies which can be treated by medications. Abnormal hemoglobin as a cause of anaemia should also be considered, as morbidity and mortality is higher in homozygous conditions of hemoglobinopathies. HPLC is a rapid, accurate and reproducible tool for early detection and proper management of hemoglobinopathies and its variants. This is especially important in view of high incidence if beta thalassemia trait in developing county like India, where resources are limited. Combined approach of primary and secondary prevention needs to be followed. It will prove to be cost effective by preventing the birth of child with genetic homozygous inheritance disease. In our study hemoglobinopathy is confined mostly to scheduled tribes (ST) or scheduled castes (SC) as compared to general caste and prevalence of hemoglobinopathies was more in SC (Mala caste). 


\section{Original Research Article}

Limitation: This data does not reflect the exact status of hemoglobinopathies in general population since this is a hospital based study. Further large scale population based studies are needed for real status of hemoglobinopathies in different caste and geographical area.

Contributions- Dr. Mahesh Kumar U conceived and planned the experiments. Miss. Devisri Y carried out the experiments. Devisri Y contributed to sample preparation.

Both Dr. Mahesh Kumar U and Miss Devisri.Y contributed to the interpretation of the results. Dr. Mahesh Kumar $U$ took the lead in writing the manuscript. Both authors provided critical feedback and helped shape the research, analysis and manuscript.

Acknowledgements: Dr. Anandam. G Prof. and HOD Pathology, PIMS, Karimnagar, Dr. Amith Kumar Associate Prof. Paediatrics, PIMS, Karimnagar and Dr. Srilatha Post graduate student, Pathology PIMS, Karimnagar and Indian Council Medical Research for accepting and funding it as STS project.

Findings: Nil; Conflict of Interest: None initiated Permission from IRB: Yes

\section{References}

1. Bittles AH. Endogamy, consanguinity and community genetics. J Genet. 2002 Dec;81(3):91-8.

2. Meena VK, Kumar K, Meena LP, Bharti A and Kumar A. Screening for Hemoglobinopathies in blood donors from eastern Uttar Pradesh. National Journal of Medical Research 2012; 2(3): 366-368.

3. Prevalence of Haemoglobinopathies. WhoExecutive Board EB118/5, 118th Session Report by the Secretariat on Thalassaemia and other haemoglobinopathies. 2006;1-8.

4. Verma P, et al. Prevalence of hemoglobinopathies in different regions \& castes of Uttar Pradesh, India -A hospital based study. Asian Journal of Medical Sciences. Sep-Oct 2015; Vol 6 (5): 21-25.

5. Chakraborti BS and Sengupta B. Prenatal Diagnosis of Thalassaemias. Int $\mathrm{J}$ Hum Genet 2002; 2(3): 173-178.

6. Lt Col PK Gupta, Col H Kumar, Lt Col S Kumar, et al. Cation exchange high performance liquid chromatography for diagnosis of hemoglobinopathies. MJAFI. 2009;65(1):33-37.
7. Higgins TN, Ridley B. Tentative identification of hemoglobin variants in the Bio-Rad VARIANT II Hb A1C method. Clin Biochem. 2005 Mar; 38(3):272-7. DOI:10.1016/j.clinbiochem.2004.11.004.

8. Sachdev R, Dam AR, Tyagi G. Detection of $\mathrm{Hb}$ variants and hemoglobinopathies in Indian population using HPLC: report of 2600 cases. Indian J Pathol Microbiol. 2010 Jan-Mar;53(1):57-62. doi: 10.4103/ 0377- 4929.59185 .

9. Joutovsky A, Hadzi-Nesic J, Nardi MA. HPLC retention time as a diagnostic tool for hemoglobin variants and hemoglobinopathies: a study of 60000 samples in a clinical diagnostic laboratory. Clin Chem. 2004 Oct; 50 (10):1736-47. DOI: 10.1373/ clinchem. 2004.034991.

10. Bhalodia JN, et al. Study of Hemoglobinopathies in patients of anemia using high performance liquid chromatography in western india. National journal of community medicine. Jan- March 2015; Vol 6 (1): 35-40.

11. Baruah MK, Saikia M, Baruah A. Pattern of hemoglobinopathies and Thalassemia in upper Assam region of North Eastern India: high performance liquid chromatography studies in 9000 patients. Indian J Pathol Microbiol. 2014 Apr-Jun;57(2):23643. doi: 10.4103/0377-4929.134680.

12. Jaskirat Singh et al. Spectrum of Hemoglobinopathies and Thalassemias Diagnosed on HPLC in A Tertiary Teaching Hospital of Northern India. National Journal of Laboratory Medicine. July 2016; 5(3): PO70-PO75.

13. Biswas $\mathrm{AK}$ and Philip J. Incidence of hemoglobinopathies and hemoglobin variants using HPLC as a diagnostic tool in 6500 anemic patients in a tertiary care center in Western India. Indian Journal of Applied Research Mar 2016;6 (3): 214-218.

14. Bhanvadia VM et al. Study of prevalence of hemoglobinopathy in Sindhi community of Jamnagar, Gujarat: A pilot study. International Journal of Medicine and Public Health Oct-Dec 2015; 5(4): 349-352.

15. Patel AG, Shah AP, Sorathiya SM, et al. Hemoglobinopathies in South Gujarat population and incidence of anemia in them. Indian $\mathrm{J}$ Hum Genet. 2012 Sep;18(3):294-8. doi: 10.4103/09716866.107979 . 
16. Ambekar SS, Phadke MA, Balpande DN, Mokashi GD, V.A. Khedkar, Banker MP, et al. The Prevalence and heterogeneity of beta thalasemia mutations in the Western Maharashtra Population: A hospital based study. IJHG 2001; 1(3): 219-223

17. Chopra GS, Nair V, Gupta PK, et al. Spectrum of Haemoglobinopathies in a Tertiary Care Hospital of Armed Forces. Med J Armed Forces India. 2008 Oct; 64 (4): 311-4. doi: 10.1016/S0377-1237(08) 80005-6. Epub 2011 Jul 21.

18. Patel J, Shrivastava A, Joshi JR, Agnihotri AS, Kaur A and Thakkar B. Detection of hemoglobinopathies and thalasemias in population of Gujarat State using HPLC: Analysis of 2022 cases. Pathology andLaboratoryMedicine2012;4(2):80-84

19.Panda A, Praveen B and Bisht SS. Clinical \& pathological status of haemoglobinopathies among pregnant women in southern Orissa. Indian Journal of Biotechnology 2009; 8(4): 456-457.
20. Sachdev R, Dam AR, Tyagi G. et al. Detection of $\mathrm{Hb}$ variants and hemoglobinopathies in Indian population using HPLC: report of 2600 cases. Indian J Pathol Microbiol. 2010 Jan-Mar;53(1):57-62. doi: 10.4103/0377-4929.59185.

21. Uddin MM, Akteruzzaman S, Rahman T, Hasan AK and Shekhar HU. Pattern of $\beta$-Thalasemia and Other Haemoglobinopathies: A Cross-Sectional Study in Bangladesh. ISRN Hematology 2012; Article ID 659191.

22. Bhasin $\mathrm{MK}$, Walter $\mathrm{H}$ and Danker-Hopfe $\mathrm{H}$. Glucose-6-phosphate dehydrogenase deficiency and abnormal hemoglobins ( $\mathrm{S}$ and $\mathrm{E}$ ) in people of India. $\mathrm{J}$ Hum Ecol 1994; 3:131-159.

23. Balgir RS. Spectrum of hemoglobinopathies in the state of Orissa, India: a ten years cohort study. J Assoc Physicians India. 2005 Dec;53:1021-6.

\section{How to cite this article?}

Mahesh Kumar U, Devisri Y. Detection of hemoglobinopathies in patients of anaemia using high performance liquid chromatography (HPLC) - a hospital based prospective study. Trop J Path Micro 2019;5(2):51-57.doi:10.17511/jopm. 2019.102.01 